\title{
Implementation of The MUI'S Fatwa No.14/2020 Concerning Worship During Pandemic: Study on Muslim Society in Ternate
}

doi.org/10.18196/afkaruna.v17i2.12554

\section{Jenjang Waldiono, Muhammad Hilali Basya}

Universitas Muhammadiyah Jakarta

hilaly.basya@yahoo.com

\begin{abstract}
This article describes how Muslims deal with fatwa through examining the extent to which Muslims in Ternate (North Maluku) respond to MUI' fatwa concerning the application of ibadah (worship) during the Covid-19 (Coronavirus) pandemic. In order to control and prevent the infection of the virus widely, people are required to stay at home and to keep their distance from crowds, including attending congregational worship (shalat jamaah) in mosques as issued in the MUI's fatwa. The fieldwork was conducted in Ternate between March-May 2021, using qualitative research methods through participatory observation and interview. This article shows that the obedience of Muslim society in Ternate to the MUI's fatwa is not only determined by aspects of the religious authority of the MUI, but also by local government, local religious leaders, and pragmatic considerations of the society as well as their perception about the dangerous impact of the Covid-19. Keywords: Covid 19 Pandemic, Fatwa, MUI, Muslims in Ternate
\end{abstract}

\section{ABSTRAK}

Artikel ini menjelaskan tentang bagaimana umat Islam menyikapi fatwa dengan mengkaji sejauh mana umat Islam di Ternate (Maluku Utara) merespon fatwa MUI nomor 14/2021 tentang pelaksanaan ibadah berjamaah di masa pandemi Covid-19. Untuk mengendalikan dan mencegah penyebaran virus secara luas, masyarakat diharuskan untuk 
tetap berada di rumah dan menjaga jarak dari keramaian, termasuk menghadiri ibadah berjamaah di masjid-masjid sebagaimana tertuang dalam fatwa MUI. Pengumpulan data (fieldwork) telah dilakukan di Ternate antara bulan Maret-Mei 2021 dengan menggunakan metode penelitian kualitatif melalui observasi partisipatif dan wawancara. Artikel ini menegaskan bahwa ketaatan umat Islam di Ternate terhadap fatwa MUI tidak hanya ditentukan oleh aspek otoritas keagamaan MUI, tetapi juga oleh pemerintah daerah, tokoh agama setempat, dan pertimbangan pragmatis masyarakat serta persepsi mereka tentang dampak berbahaya dari Covid-19.

Keywords: Fatwa, MUI, Masyarakat Muslim Ternate, Pandemi covid 19

\section{INTRODUCTION}

Discussion about the role of fatwa in Muslims' life and how they deal with fatwa is interesting. The term "fatwa" derives from the Arabic language, and then it is absorbed as an Indonesian term. Generally, fatwa is defined as a legal opinion produced by a religious scholar (ulama). ${ }^{1}$ It is given to those asking questions about religious issues, such as in faith or prayer. The person requesting a fatwa is called mustafti. Basically, fatwa is not binding. ${ }^{2}$ It is only an opinion that may be obeyed or abandoned by its mustafti or other Muslims. However, fatwa plays an important role in shaping Muslims' life either in religious dimensions or social aspects. ${ }^{3}$

Fatwa issued by the Council of Indonesian Ulama or called MUI in dealing with congregational worship during Pandemic is one of the examples of how the fatwa is utilized to play a role in shaping the religious and social life of Muslims in Indonesia. In recent 15 months, Indonesia and other countries worldwide are being challenged by Coronavirus named Covid-19. The outbreak of the virus becomes pandemic and forces people to establish new normality such as wearing a mask in the public area, keeping social distance, and performing congregational prayer.

Many studies about fatwa have been done. Some of the previous studies examined the method of producing fatwa. ${ }^{4}$ Other studies investigated factors making a fatwa authoritative ${ }^{5}$ and how the nature of fatwa is in the particular religious community like $\mathrm{NU}^{6}$ and Muhammadiyah. ${ }^{7}$ 
Although many studies about fatwa have been done, few investigations have been conducted about the effectiveness of MUI's fatwa regarding congregational worship during the pandemic. Performing congregational prayer during a pandemic is a new context in which Muslims need practical advice that assists them on how to deal with religion and this deadly virus. Based on this consideration, this article aimed to reveal: 1) how do Muslims in Ternate (North Maluku), the eastern part of Indonesia, deal with the MUI's fatwa; 2) what are the factors influencing their responses to the fatwa.

Data collection has been conducted in Ternate between March-May 2021. The method applied is qualitative through participatory observation and interview. I observed several mosques in Ternate City, especially the Al-Munawwar Grand Mosque, the main mosque and symbol of the Muslim community in Ternate. Other mosques observed are Darul Arqom which is maintained by the Muhammadiyah community, Al-Muttaqien mosque and Babul Jannah mosque, respectively, managed by Nahdhatul Ulama (NU) community and Wahdatul Islamiyah (regarded as Salafi community). The interview had been conducted with the local government of Ternate, local religious leaders, as well as congregants of the mosques.

This article argues that the obedience of Muslim society in Ternate to the MUI's fatwa is not only determined by aspects of the religious authority of the MUI, but also by the role of local government and local religious leaders, and pragmatic considerations of the society as well as their perception about the dangerous impact of the Covid-19.

\section{CONTEXT OF THE FATWA AND RESPONSE OF LOCAL GOVERNMENT AND OTHER LOCAL LEADERS TO THE FATWA}

Currently, the world is being hit by the Covid-19 or known as the Coronavirus pandemic. This virus disrupts the respiratory system and causes a very high death rate. It spreads through respiratory droplets between humans and objects touched by contaminated subjects. With the Covid-19 outbreak, the world is entering a new phase in carrying out daily life activities. All world leaders, including the Indonesian government, have implemented various policies to minimize and prevent 
the chain of the spread of this deadly virus. The Indonesian government implemented a large-scale restriction policy (called PSBB). The policy is issued through the Regulation of the Minister of Health (Permenkes) ${ }^{8}$ so that it is mandatory and binding for all Indonesian people.

As an effort to support the success of this government's program, the Council of Indonesian Ulama (or called MUI) has issued a fatwa number 14 of 2020 concerning the maintenance of worship in a situation of the Covid-19 pandemic. The MUI is Indonesia's top Muslim clerical institution which was founded as a body to produce fatwa and to advise the Indonesian Muslim community on contemporary issues. ${ }^{9}$ Therefore, the release of the fatwa is one of the functions of the MUI, which is to guide Muslims' religious life in dealing with the pandemic situation.

The MUI's fatwa number 14 issued in 2020 aims to support the government programs in preventing the transmission of dangerous diseases. The substance of the fatwa is sort of the implementation of maqasid shariah (the goal of sharia), namely hifzun nafs (keeping human life). Here is the fatwa, particularly in point 3 :

Orang yang sehat dan yang belum diketahui atau diyakini tidak terpapar Covid-19, harus memperhatikan hal-hal sebagai berikut: (a) Dalam hal ia berada di suatu kawasan yang potensi penularannya tinggi atau sangat tinggi berdasarkan ketetapan pihak yang berwenang maka ia boleh meninggalkan shalat Jumat dan menggantikannya dengan shalat zuhur di tempat kediaman, serta meninggalkan jamaah shalat lima waktu/rawatib, Tarawih, dan led di Masjid atau tempat umum lainnya. (b) Dalam hal ia berada di suatu kawasan yang potensi penularannya rendah berdasarkan ketetapan pihak yang berwenang maka ia tetap wajib menjalankan kewajiban ibadah sebagaimana biasa dan wajib menjaga diri agar tidak terpapar Covid-19, seperti tidak kontak fisik langsung (bersalaman, berpelukan, cium tangan), membawa sajadah sendiri, dan sering membasuh tangan dengan sabun. ${ }^{10}$

People who are healthy and who are not yet known or identified to have not been infected by Covid-19 must pay attention to the following regulations: (a) In a situation that Muslims who are living in an area with a high or very high potential transmission based on the provisions of the competent authority are allowed to leave the Friday 
prayer and replace it with the Zuhur prayer at their own residences, and are also allowed to leave the congregation prayer (shalat jamaah) for the five daily prayers, Tarawih (congregational prayer in Ramadhan nights), and Eid prayer in a mosque or other public places. (b) In a situation that Muslims who are living in an area with a low transmission which is based on the provisions of the competent authority are still obliged to carry out worship as usual and must protect themself from being infected by Covid-19, such as not to make direct physical contact (shaking hands, hugging, kissing hands), to bring their own prayer mats, and wash their hands frequently with soap. ${ }^{11}$

Based on the points, it is worth emphasizing that the purpose of this MUI' fatwa is to prevent the massive spread of Covid-19 in Indonesia, especially among the Muslim community. This fatwa attempts to maintain how Muslims, during the Covid-19 pandemic, can perform congregational prayer or any other worships without causing harm to each other, as explained by one of the members of MUI Ternate:

This fatwa comes from the Central MUI, and indeed one of the functions of the MUI is to provide understanding, especially to Muslims. So that in this pandemic atmosphere where we know how the virus spreads, which is through touching, coughing, sneezing and other splashes, Muslims are expected to be able to prevent the spread to other Muslims by managing and also regulating the congregational prayer and other worship in public places. So the fatwa departs from the principle of figh rule dar'u al-mafasid muqoddam min jalbi al-masalih, which means, "Avoiding danger or damage must be prioritized over seeking good." This principle advises Muslims to avoid massive dissemination of the virus. ${ }^{12}$

Responding to this MUI's fatwa, the Gamalama ${ }^{13}$ government conducts various socialization efforts to the community. The socialization process carried out by the local government involves various levels of community elements such as Satgas Covid (the Covid-19 Task Force), youth organizations, and institutions managing mosques (or called BKM), as well as community leaders such as RT (Rukun Tetangga) and RW (Rukun Warga). As stated by the Head of Community Empowerment of the Gamalama, Imy Liawati: 
All elements of Gamalama society cooperate with each other, both the village, the community, the Satgas Covid-19, youth organizations and BKM mosques. Everyone works together, so they support each other. It also includes utilizing community leaders in each RT and RW to provide socialization to residents. ${ }^{14}$

The involvement of community leaders in the socialization program was justified by Dzamrud Muchsin as the imam (head) of the Al-Munawwar Grand Mosque and a community figure who has a great influence among the Muslim community: "the local government has asked my help to remind jama'ah (people performing prayer in the mosque) to be committed with social distancing and using masks in the mosque during congregational worship and in other public places."

The same role has also been played by the Ternate branch MUI. The action involves not only community leaders like the head of RT and RW, but also by disseminating the message through majelis-majelis taklim (forums of religious teaching), by publishing articles in a local newspaper named Malut Post, collaborating with military detachment (Korem Transportation Detachment or called Denhubrem) which has regular programs on local cable TV broadcasts as well as preaching program which is broadcasted through Ternate City RRI (Radio of Republic of Indonesia):

We disseminate information to the public through various media, such as RRI. We, from the MUI, every morning take turns to deliver tausiyah (preaching) at subuh prayer. We also implicitly deliver messages related to the MUI's fatwa, likewise in majelis taklim (forum of religious teaching) and interviews like this. We also wrote several times in the Malut Post to socialize this problem and the MUI's fatwa at the beginning of the pandemic. We also collaborated with Denhubrem (Korem Transportation Detachment), where they have a program on their local television channel named SBCV, where every Friday night, we from MUI deliver tausiyah there, and we always socialize the MUI's fatwa. And finally, we also collaborate with community leaders, including the head of RT and RW. ${ }^{16}$

Based on the data above, it can be concluded that the local government of Gamalama and the MUI of Ternate City always try their best to disseminate the fatwa in order to prevent the spread of the 
Covid-19 virus, particularly related to Muslim congregational worship. This is also further strengthened by the procurement of standard health facilities carried out by the government, as explained by Imy Liawati:

Gamalama Village often conducts socialization to the community requiring them to wear masks, use hand sanitizers, spray disinfectants regularly, which is once a week in every mosque, and provide water and soap containers for washing hands. ${ }^{17}$

After conducting socialization and providing various facilities to support the implementation of health protocols to the community, strict control of the apparatus are applied to violators of health protocols in the implementation of congregational prayers in the mosques by giving warnings and providing masks for free to the violators after being reprimanded and educated, as told by Imy Liawati:

At the beginning of the pandemic, when people disobeyed and did not use masks, the Gamalama government would give a warning. We also regularly educate the community and provide health attributes such as masks for free. ${ }^{18}$

\section{THE DECLINE OF COMPLIANCE}

However, in practice, public compliance with health protocols when performing congregational worship at the mosque only lasts at least the initial three months since the first positive case of Covid-19 contamination in Ternate City. As expressed by Imy Liawaty: "But it is no longer practiced here, it only happened at the beginning of the pandemic, about three months. As for now, congregational prayers at the mosque are back to normal as usual before the pandemic."19

Based on my observation, congregational prayers in mosques no longer apply the health protocol. I observed several mosques in Ternate City, including the main mosque, which is the symbol of the Muslim community in Ternate City, namely the Al-Munawwar Grand Mosque. Friday prayer in this Grand mosque during the pandemic seems to be going on as usual. The number of worshipers who throng the Al-Munawar Grand Mosque is fairly crowded until half of the first-floor mosque is fully filled. It is estimated around thousands of people, considering the capacity of Al-Munawar, which is 15.000 people. This is 
like the situation before the pandemic. Congregations aged over 60 years (lansia) who are vulnerable to Covid-19 infection are still found many attending Friday prayers in the mosque. Almost all who attended the congregational prayer did not use masks. Only a small number of worshipers were aware of wearing masks. Actually, the management of Al-Munawar mosque has attached a banner stating "Masks required area" at several points of the mosque. I also found that shaf (line) of the congregation does not have physical distancing and stays tight as usual. However, at the end of the Friday prayer, the jamaah did not shake hands with each other as commonly practiced before the pandemic.

Based on the observation made at the Al-Munawar Grand Mosque, the implementation of the five daily prayers are no different from the Friday prayers. Almost all of the congregation who attended did not use masks. Only a small number of worshipers were aware of wearing masks. Shaf (line of worshipers) of the congregation does not have physical distancing and stays tight as usual. However, they did not shake hands with each other. I interviewed some of them, asking why they do not use the mask. One of them said that he forgot to bring a mask, while the other said that they feel uncomfortable and annoyed because hard to breathe when wearing masks. Besides the uncomfortable reason, they are also not afraid of getting infected, as they said.

A similar attitude is also found in the Muhammadiyah mosque named Darul Arqom. One of the congregations in the mosque said that he no longer wears a mask when he leaves his house and performs congregational prayers:

Unlike at the beginning of the pandemic, recently, I rarely use a mask, even almost never now. The reason I do not use any masks now is that many people do not use masks either, and no one has warned me. So I just imitate them. ${ }^{20}$

The same thing was found in a smaller mosque within the community. One of the informants said that "the decline of the compliance is affected by local environmental conditions that no longer work as in the beginning." 21 
Then, I visited and made observations at several mosques belonging to Islamic organizations (ormas) as a comparison regarding the implementation of the 5 daily prayers. One of them was Al-Muttaqin Grand Mosque which belongs to Nahdhatul Ulama or called NU (a traditionalist Islamic organization in Indonesia). I found that this mosque does not implement health protocols. Prayer rugs or prostration carpets are provided by the mosque in the front row. There are many worshipers that their ages are over 65 years old attending this mosque for congregational prayers. The congregation does not seem worried when they shake hands with each other after praying. Almost all of the congregation did not use masks. Moreover, there is no call for a mandatory mask area made by the BKM (mosque management). The percentage that does not use the mask in this mosque is much larger than other mosques. ${ }^{22}$

The same thing was found at the Babul Jannah mosque, located in the Moloku Kie Raha Islamic Boarding School. The mosque is managed by Wahdah Islamiyah, an Islamic revivalist movement classified by experts as a Salafi group. The implementation of the 5 daily prayers at the Babul Jannah mosque also does not apply physical distancing shown by the rows of congregations are still very close. Furthermore, the majority of the congregation does not wear masks. There is no requirement from the mosque management to wear it. However, it seems that the congregations recognize the danger of staying longer after the pray. Most of them left the mosque after finishing the prayer. There are no carpets or prayer mats in the congregation's prostration area, and there are no vulnerable age groups above 60 years. ${ }^{23}$

The last mosque that I visited in this area was a mosque managed by Muhammadiyah of Ternate City, namely the Darul Arqom Mosque. There is not much difference concerning the implementation of the 5 daily prayers at this mosque. Worshipers at the mosque almost entirely do not wear masks. Only a small number of the worshipers wore the masks. There is no banner reminding about the mandatory wearing of masks in the Darul Arqam Mosque. The members of the congregation at the Darul Arqam Mosque also do not apply physical distancing and remain to chat 
after the prayer. However, there is no prayer rug at the congregational prostration area and no vulnerable age groups over 60 are praying at the mosque. ${ }^{24}$

Several mosques in Ternate City, including the Al-Munawwar Grand Mosque, commemorated the Isra Mi'raj. In this year attendances were much lesser than previous years. Furthermore, the commemoration itself this year was not managed by the Ternate City government as usual, but it was carried out by a student community who are members of KAMMI (a young Islamic organization that is affiliated with an Islamist political party named Partai Keadilan Sejahtera (PKS). It was also seen that only a small proportion of those who attended the Isra Mi'raj wore masks. Moreover, many of them sat closely with each other in rows. At the end of the activity, many of them still shook hands like in a normal situation.

Al-Munawwar Grand Mosque has routine activities. Some of them are religious lectures (pengajian) conducted every Sunday after maghrib and Friday after Subuh (morning before sunrise). In both lectures, the majority of the people present do not use masks and do not apply physical distancing as well as kissing the hand of the ustadz (religious teacher) who gave the Islamic subjects. At the same time, activities of Qur'an studies for children (TPA and Raudhatul Athfal) have been conducted online since the beginning of the pandemic.

In the recent last six months (November 2019 - April 2021), the implementation of health protocols in the community has become increasingly lax. ${ }^{25}$ Furthermore, since the beginning of 2021, especially the last two months (March to April), most people really do not care anymore about health protocols. ${ }^{26}$

The public's indifference regarding the application of health protocols and social restrictions instructed by the MUI has relation with the Ternate City Covid-19 Task Force (Satgas Covid-19), which no longer actively updates the development of the number of Covid-19 patients in Ternate City. The absence of such information led people to think that the Covid-19 had disappeared from Ternate City. This was stated by the chairman of the MUI of Ternate, Usman Ibrahim: "One of the factors that make people no longer care is because initially the Covid-19 Task Force 
(Satgas Covid-19) always released the development of the number of cases infected with the coronavirus, while now there are no more updates from the Covid-19 Task Force. So my personal analysis is that this factor causes people to think that Covid-19 in Ternate is over, and it does not exist anymore."27

Based on the interviews and observations, it can be concluded that the people of Ternate City were initially very obedient to health protocols by always wearing masks, maintaining distance, washing hands with soap and using hand sanitizers when carrying out activities outside the home, including praying together at mosques. However, due to the disappearance of the Covid-19 task force (Satgas Covid-19) of Ternate City in providing information and socialization about Covid-19, most people feel that Covid-19 is no longer exists in Ternate City. On the other hand, the government and related parties have also been unable to control and take firm action against people who feel bored with the issue of Covid-19.

\section{FACTORS INFLUENCING THE COMPLIANCE AND ABANDONMENT OF THE FATWA}

Some factors are supporting the implementation of the MUI fatwa number 14 of 2020 regulating the congregational prayer at mosques in the situation of the Covid-19 outbreak in Ternate City. The first is the synergy of various elements of society such as local religious leaders, mosques' management (BKM), the local government, the Covid-19 Task Force, community leaders, and youth organizations. This synergy shows public awareness of the importance of social restrictions and the application of the health protocols contained in the fatwa. Public awareness is the main and most important factor in implementing the fatwa in Ternate City can run well. Among the forms of community support related to implementing the fatwa is always to apply health protocols, namely maintaining distance, using masks, washing hands and avoiding crowds. This was conveyed by the Head of Community Empowerment of Gamalama Village:

Everyone cooperates with each other, both the village, the community, the Covid-19 Task Force, youth organizations and BKM Mosque. Everyone works together, so they support each other. It also 
includes utilizing community leaders in each RT and RW to provide socialization to residents. Because Gamalama is known as the economic center in Ternate, so it is the most vulnerable area. All Ternate people inevitably go to Gamalama, so all elements must complement and support each other.

The same thing regarding public awareness was emphasized by Rafli Umar: "the attention and cooperation of the mosque management are very important in implementing health protocols for the congregation in the mosque." 29

The factor greatly influencing public awareness is clear and good information delivered to the community. So that the second supporting factor is the socialization carried out by the government and the MUI branch of Ternate City. Some of the efforts done by the MUI is utilizing various kinds of media, such as collaborating with Radio of Republic of Indonesia (RRI) of Ternate City, through writing on social media such as Facebook and print media such as newspapers in disseminating the MUI's fatwa to the public. In addition, the MUI of Ternate City also cooperated with a local television station in collaboration with the Denhubrem (Korem Transportation Detachment). This collaboration supports the dissemination of the fatwa to reach a wider audience. Furthermore, the dissemination also utilizes forums of religious teaching (majelis ta'lim) and collaboration with community leaders in order to ensure that information about the fatwa can be heard and understood by the public as told by the chairman of the MUI of Ternate City:

I think the supporting factor is the media, such as RRI. Alhamdulillah, when we were on air (live) at RRI, there were a lot of questions from the audience, not only from Ternate but also from Sulawesi, Sumatra, Bogor, etc. Alhamdulillah, the government is also very supportive, including the health department and the Covid-19 Task Force team. It is also worth noting the role played by local newspapers and television, such as Gamalama TV, in disseminating information issued in the MUI's fatwa. ${ }^{30}$

Another factor that supports the dissemination of the MUI's fatwa is the publication of a guidebook for the implementation of worship during the pandemic, as told by Rafli Umar: "there is a guidebook for the 
implementation of worship during the pandemic." ${ }^{131}$ This guidebook, which is distributed free of charge, can be utilized for reference and knowledge by the community in carrying worship during the pandemic.

Health facilities and infrastructure provided by the local government also play an important role in the successful implementation of the MUI's fatwa. Procuring masks, hand sanitizers, spraying disinfectants once a week in every mosque, as well as providing water and soap containers for washing hands at the entrance to the mosque are some of the facilities provided. With these health facilities and infrastructure, the community can feel safe and comfortable in worshiping at the mosque, even in the atmosphere of the Covid-19 pandemic.

In the implementation of the MUI fatwa number 14 of 2020 regarding congregational worship in a situation where the Covid-19 outbreak occurred in the City of Ternate, there were several factors inhibiting its success. The main factor hindering the implementation of the fatwa is the lack of knowledge in the community, and they rely more on non-scientific views, so their understanding of the covid-19 is not in line with health workers and the MUI's fatwa. This lack of knowledge is closely related to the culture or hereditary habits practiced by the community so that people are not ready to face the unexpected realities of life. This Covid-19 pandemic inevitably forces humans to adapt to new challenges or reality. This deadly virus has changed not only the social life of a city but also the world globally. The Muslim community of Ternate City, which culturally and from generation to generation has always performed congregational prayers by tightening the rows, is now forced to stretch the rows and keep their distance. A sudden change like this makes people unprepared to oppose it. The majority of people feel that tight and straight rows are an obligation under any conditions or circumstances without exception, as has been done by traditional communities for generations. As the chairman of MUI of Ternate City said:

I think one of the main factors preventing many people from obeying MUl's fatwa is lack of knowledge. Our Muslim brothers from the Jamaah Tabligh, for instance, after I taught in a forum after subuh (morning before sunrise) at the Grand Mosque, some members of the 
Jama'ah Tabligh came to me and protested why the rows are so far apart. $^{32}$

The next inhibiting factor is the discomfort when wearing a mask, as told by one of the informants: "I also feel disturbed when I use a mask. During praying, I do not use the mask. It is uncomfortable, annoying, stuffy and hard to breathe."33

Another factor that hinders the implementation of this fatwa is that some people still do not believe in the existence of Covid-19. According to them, Covid-19 is a global conspiracy or political maneuver of political elites and the government as stated by one of the informants: "many who do not believe about this Covid-19 outbreak think that this outbreak is a political game of people in government." 34 The same thing was informed by Rafli Umar: "many people think that Covid-19 is a conspiracy, so they ignore the health protocols." 35 Probably, those who think like this have never seen a case of a person contaminated with the Covid-19 and only found out through the news in the media.

The other factor that becomes an obstacle is the lack of public awareness to implement health protocols. This was explained by some informants such as Rafli Umar, "The hindering factor, in my opinion, is the lack of awareness of the congregation about the dangers of Covid 19." ${ }^{36}$ Then again, expressed by Desy Vita Pratiwi: "One of the inhibiting factors for the implementation of the MUI fatwa is the lack of public awareness to implement health protocols." 37 And what was said by Irfandi Raja Bunga, "The lack of public awareness has resulted in being indifferent." 38

Another problem that hinders the successful implementation of the MUI's fatwa is the lack of public literacy. Muslims in Ternate City cannot filter the information that they receive. Hoax news about Covid-19 and the absence of the Covid-19 Task Force (Satgas of Covid-19) recent six months in Ternate City led the people to think that the Covid-19 virus has disappeared in Ternate City, as stated by Irfandi Raja Bunga:

The public's lack of awareness is the cause making people being indifferent. Probably, it is also caused by public literacy and lack of transparency of the government and the Satgas of Covid-19. Recently 
there have been no more updates on the number of victims from the Satgas. Their offices are also closed. Therefore people think that this corona is no longer in Ternate. In addition, there is also a lot of hoax information that is spread in the community and on social media. And people also think that death is destiny from Allah, so they don't have to be afraid of the corona. ${ }^{39}$

What Irfandi said that the Covid-19 Task Force was no longer active was confirmed by the chairman of MUI of the Ternate City:

One of the factors that make people no longer care is because initially, the Covid-19 Task Force (Satgas) always released the development of the number of cases contaminated with this coronavirus, while now there are no more updates from the Covid-19 Task Force. So my personal analysis is that it is one of the factors that cause people to think that Covid-19 in Ternate is over, and it does not exist anymore. ${ }^{40}$ These all factors show that the MUI's fatwa has been abandoned by Ternate society, including local religious leaders maintaining the mosques. Even though they, to some extent, obey and respect the religious authority of the $\mathrm{MUI}$ as indicated by their obedience in the early phase of the pandemic, the declining role of Satgas Covid-19 in recent six months, as well as people, own consideration assuming that the virus is not dangerous and has disappeared from Ternate led them to neglect the fatwa. Therefore, although the fatwa is crucial in helping the local government to obey health protocol, it requires other variables in order to make the fatwa works maximally in society.

\section{CONCLUSION}

This article reveals how Muslims in Ternate (North Maluku) respond to MUI's fatwa concerning the application of congregational worship during the Covid-19 pandemic. Due to the outbreak of the virus in Indonesia, the government seeks to control and prevent the spread of the virus. Through regulation, the government requires people to stay at home and to keep their distance from crowds. Supporting this regulation, the MUI released a fatwa restricting Muslims from attending congregational worship (shalat jamaah) in mosques. 
How Muslims in Ternate deal with the MUI's fatwa and the factors influencing their responses to the fatwa were the questions that would be answered in this article. Relevant parts of the fatwa, as well as context in which the fatwa was issued, are also described.

The local government of Ternate, local religious leaders as well as the MUI of Ternate play an important role in disseminating the fatwa, particularly related to the Muslim congregation, in order to prevent the spread of the Covid-19 virus. However, in practice, public compliance with health protocols when performing congregational worship at the mosque only lasts at least the initial three months since the first positive case of Covid-19 contamination in Ternate City.

Based on the interviews and observations, the people of Ternate City were initially very obedient to health protocols by always wearing masks, maintaining distance, washing hands with soap and using hand sanitizers when carrying out activities outside the home, including praying together at mosques. However, due to the disappearance of the Covid-19 task force (Satgas Covid-19) of Ternate City in providing information and socialization about Covid-19, most people feel that Covid-19 is no longer exists in Ternate City. These all show that obedience of Muslim society in Ternate to the MUI's fatwa is not only determined by aspects of the religious authority of the $\mathrm{MUI}$, but also by the role of local government, local religious leaders, and pragmatic considerations of the society as well as their perception about the dangerous impact of the Covid-19.

\section{ENDNOTES}

1 M. B. Hooker, Indonesian slam: Social Change through Contemporary Fatawa (Honolulu: University of Hawai Press, 2003).

2 Nico J. G. Kaptein, "The Voice of the Ulama: Fatwas and Religious Authority in Indonesia," Archives de Sciences Sociales des Religions, 125, (Janvier-Mars 2004): 115-130.

3 Nico J. G. Kaptein, "The Voice of the Ulama: Fatwas and Religious Authority in Indonesia." see also M Hilali Basya, "The Concept of Religious Pluralism in Indonesia: a Study of the MUI's Fatwa and the Debate among Muslim Scholars," IJIMS (Indonesian Journal of Islam and Muslim Societies), 1, 1 (2011): 69-93.

4 Nico J. G. Kaptein, "The Voice of the Ulama: Fatwas and Religious 
Authority in Indonesia." See also M Hilali Basya, "Muhammadiyah's Fatwa about Hewan Kurban in 2005: A Study on Muhammadiyah's Method in Producing Fatwa," Afkaruna, 15, 1 (2019): 1-18.

5 Mohammad Syifa Amin Widigdo, "The Power of Fatwa in Indonesia: An Analysis of MUI's Controversial Fatwâs," Afkaruna, 14, 2 (2018): 146-165.

6 Michael Laffan, "The fatwā Debated? Shūrā in One Indonesian Context," Islamic Law and Society, 12, 1 (2005): 93-121

7 M Hilali Basya, "Muhammadiyah's Fatwa about Hewan Kurban in 2005: A Study on Muhammadiyah's Method in Producing Fatwa."

8 Peraturan Menteri Kesehatan (Permenkes) RI Nomor 9 Tahun 2020.

9 Piers Gillespie, “Current Issues in Indonesian Islam: Analyzing the 2005 Council of Indonesian Ulama Fatwa No.7 Opposing Pluralism, Liberalism, and Secularism," Journal of Islamic Studies, 2, 18 (2007): 1-39.

10 Fatwa MUI nomor 14 tahun 2020.

11 The text is translated by the corresponding author.

12 Interview with the chairman of MUI of Ternate, Usman Ibrahim, on 2nd April 2021.

13 Gamalama is one of the sub-districts of Ternate City in which the fieldwork has been conducted.

14 Interview with the Head of Community Empowerment of the Gamalama, Imy Liawati, on $1^{\text {st }}$ April 2021.

15 Interview with Dzamrud Muchsin, the imam (head) of the Al-Munawwar Grand Mosque, on $28^{\text {th }}$ March 2021.

16 Interview with the chairman of MUI of Ternate, Usman Ibrahim, on $2^{\text {nd }}$ April 2021.

17 Interview with the Head of Community Empowerment of the Gamalama, Imy Liawati, on $1^{\text {st }}$ April 2021.

18 Interview with the Head of Community Empowerment of the Gamalama, Imy Liawati, on $1^{\text {st }}$ April 2021.

19 Interview with the Head of Community Empowerment of the Gamalama, Imy Liawati, on $1^{\text {st }}$ April 2021.

20 Interview with Muhammad Dzulfiqram, a congregant in Darul Arqom Mosque, on $15^{\text {th }}$ April 2021.

21 Interview with Rafli Umar, a congregant of Babul Jannah, 10 ${ }^{\text {th }}$ April 2021.

22 Observation at Grand Mosque of Al-Muttaqin on 07 ${ }^{\text {th }}$ April 2021

23 Observation at Babul Jannah mosque on $6^{\text {th }}$ April 2021.

24 Observation at Darul Arqam Mosque on $5^{\text {th }}$ April 2021.

25 Interview with the Head of Community Empowerment of the Gamalama, Imy Liawati, on $1^{\text {st }}$ April 2021.

26 Interview with the Head of Community Empowerment of the Gamalama, Imy Liawati, on $1^{\text {st }}$ April 2021.

27 Interview with the chairman of MUI of Ternate, Usman Ibrahim, on $2^{\text {nd }}$ 
28 Interview with the chairman of MUI of Ternate, Usman Ibrahim, on $2^{\text {nd }}$ April 2021.

29 Interview with the Head of Community Empowerment of the Gamalama, Imy Liawati, on $1^{\text {st }}$ April 2021.

30 Interview with Rafli Umar, a congregant of Babul Jannah, 10th April 2021.

31 Interview with the chairman of MUI of Ternate, Usman Ibrahim, on 2nd April 2021.

32 Interview with Rafli Umar, a congregant of Babul Jannah, 10 ${ }^{\text {th }}$ April 2021.

33 Interview with the chairman of MUI of Ternate, Usman Ibrahim, on 2nd April 2021

34 Interview with Irfandi Raja Bunga, a congregant of Al-Munawwar Grand Mosque on $25^{\text {th }}$ March 2021.

35 Interview with Desy Vita Pratiwi, a congregant of Al-Muttaqin Great Mosque, on $15^{\text {th }}$ April 2021.

36 Interview with Rafli Umar, a congregant of Babul Jannah, 10 ${ }^{\text {th }}$ April 2021.

37 Interview with Rafli Umar, a congregant of Babul Jannah, 10 ${ }^{\text {th }}$ April 2021.

38 Interview with Desy Vita Pratiwi, a congregant of Al-Muttaqin Great Mosque, on $15^{\text {th }}$ April 2021

39 Interview with Irfandi Raja Bunga, a congregant of Al-Munawwar Grand Mosque on $25^{\text {th }}$ March 2021.

40 Interview with Irfandi Raja Bunga, a congregant of Al-Munawwar Grand Mosque on 25 $5^{\text {th }}$ March 2021.

41 Interview with the chairman of MUI of Ternate, Usman Ibrahim, on $2^{\text {nd }}$ April 2021.

\section{REFERENCES}

Basya, M. Hilali, 'Muhammadiyah's Fatwa about Hewan Kurban in 2005: A Study on Muhammadiyah's Method in Producing Fatwa," Afkaruna, 15, 1 (2019): 1-18.

Basya, M. Hilali, "The Concept of Religious Pluralism in Indonesia: a Study of the MUI's Fatwa and the Debate among Muslim Scholars," IJIMS (Indonesian Journal of Islam and Muslim Societies), 1, 1 (2011): 69-93.

Gillespie, Piers, "Current Issues in Indonesian Islam: Analyzing the 2005 Council of Indonesian Ulama Fatwa No.7 Opposing Pluralism, Liberalism, and Secularism," Journal of Islamic Studies, 2, 18 (2007): 1-39.

Hooker, M. B. Indonesian slam: Social Change through Contemporary Fatawa (Honolulu: University of Hawai Press, 2003).

Kaptein, Nico J. G. "The Voice of the Ulama: Fatwas and Religious Authority in Indonesia," Archives de Sciences Sociales des Religions, 125 (Janvier-Mars 2004): 115-130.

Laffan, Michael, "The fatwā Debated? Shūrā in One Indonesian Context," Islamic Law and Society, 12, 1 (2005): 93-121.

Widigdo, Mohammad Syifa Amin, "The Power of Fatwa in Indonesia: An Analysis of MUI's Controversial Fatwâs," Afkaruna, 14, 2 (2018): 146-165.

Interview with the chairman of MUI of Ternate, Usman Ibrahim, on 2nd April 2021.

Interview with the Head of Community Empowerment of the Gamalama, Imy Liawati, on 1st April 2021.

Interview with Dzamrud Muchsin, the imam (head) of the Al-Munawwar Grand Mosque, on 28th March 2021. 
Fatwa MUI no. 14 tahun 2020.

Peraturan Menteri Kesehatan (Permenkes) RI Nomor 9 Tahun 2020. 